\title{
Liver fungal infections: an overview of the etiology and epidemiology in patients affected or not affected by oncohematologic malignancies
}

This article was published in the following Dove Press journal:

Infection and Drug Resistance

\author{
Marco Fiore ${ }^{1, *}$ \\ Marco Cascella ${ }^{2, *}$ \\ Sabrina Bimonte ${ }^{2}$ \\ Alberto Enrico Maraolo 3 \\ Ivan Gentile ${ }^{3}$ \\ Vincenzo Schiavone ${ }^{4}$ \\ Maria Caterina Pace' \\ 'Department of Anaesthesiological, \\ Surgical and Emergency Sciences, \\ University of Campania "Luigi \\ Vanvitelli”, Naples, Italy; ${ }^{2}$ Department \\ of Support for Clinical Activities and \\ Critical Area, Division of Anesthesia \\ and Pain Medicine, Istituto Nazionale \\ Tumori - IRCCS “Fondazione G. \\ Pascale",Via Mariano Semmola, \\ Naples, Italy; ${ }^{3}$ Department of Clinical \\ Medicine and Surgery, Section of \\ Infectious Diseases, University of \\ Naples Federico II, Naples, Italy; \\ ${ }^{4}$ Division of Anesthesia and Intensive \\ Care, Hospital "Pineta Grande", \\ Castel Volturno, Italy \\ *These authors contributed equally to \\ this work
}

Correspondence: Sabrina Bimonte Division of Anesthesia and Pain Medicine, Istituto Nazionale Tumori - IRCCS

"Fondazione G. Pascale", Via Mariano Semmola, 80I3I Naples, Italy

Tel +39 08I 590322 I

Email s.bimonte@istitutotumori.na.it

\begin{abstract}
Fungal infections of the liver, most commonly caused by Candida spp., often occur in patients with hematologic malignancies treated with chemotherapy. Colonization of the gastrointestinal tract is thought to be the main origin of dissemination of Candida; mucositis and neutropenia facilitate the spread of Candida from the gastrointestinal tract to the liver. Hepatic involvement due to other fungi is a less common infectious complication in this setting. Fungal infections represent a less common cause of hepatic abscesses in non-oncohematologic population and the trend appears to be decreasing in recent years. Understanding of the etiology and epidemiology of fungal infections of the liver is indicated for an appropriate antimicrobial therapy and an overall optimal management of fungal liver infections.
\end{abstract}

Keywords: fungal liver infections, antifungal agents, hepatosplenic candidiasis, acute disseminated candidiasis, life-threatening infections

\section{Background}

Invasive fungal infections (IFIs) have become a leading cause of morbidity and mortality in oncohematologic patients and hematopoietic stem cell transplantation (HSCT) recipients. ${ }^{1}$ Overall, Candida spp. are a leading cause of fungal liver infections in oncohematologic patients. Hepatic involvement due to yeasts other than Candida spp., molds, and dimorphic fungi is a less common, but severe, infectious complication in this setting. Fungal infections represent $<2 \%$ of the total isolates in pus from hepatic abscesses in patients without oncohematologic malignancies. ${ }^{2,3}$ This review will briefly touch upon the etiology and epidemiology of fungal infections among patients with or without oncohematologic malignancies in order to suggest the adequate management of these entities.

\section{Materials and methods}

A literature search using the MEDLINE database up to February 2017 was performed in order to identify all papers on liver fungal infections. A full-text search by using the MeSH terms "liver fungal infections" OR "fungal liver abscess" OR "fungal hepatic abscess" was conducted. A review of the bibliographies of relevant articles was also performed. Results were categorized and summarized according to the host characteristics (patients with or without oncohematologic malignancies, neonates and children, liver transplantation, and human immunodeficiency virus [HIV]) and the etiology (Candida, Aspergillus, other fungi). Finally, we synthesized the various liver fungal infections in the different clinical settings (Table 1), the findings from studies 
on hepatosplenic candidiasis (HSC) in patients with oncohematologic malignancies (Table 2), the findings from studies on liver fungal infections in patients who had undergone liver transplantation (Table 3), and the uncommon causes of liver fungal infections in patients with (Table 4) or without (Table 5) oncohematologic malignancies.

\section{Patients with oncohematologic malignancies \\ Candida}

HSC is a serious infective complication in oncohematologic patients. ${ }^{4-6}$ Before the widespread use of antifungal prophylaxis, HSC occurred in $<10 \%$ of patients with hematologic malignancies, mainly acute leukemia, or after HSCT, mainly allogeneic $\mathrm{HSCT}^{7}$ Today, thanks to the primary systemic antifungal prophylaxis, the incidence of HSC has significantly reduced. ${ }^{8,9}$ Anttila et al, in a retrospective Finnish study conducted from 1980 to 1993, observed 38 (6.8\%) cases of HSC among 562 adult patients with acute leukemia. The incidence was higher among patients with acute lymphatic leukemia (ALL) than among those with acute myeloid leukemia (AML; $11.3 \%$ versus 5.1\%, respectively; $P=0.01)$. The median duration of severe neutropenia (absolute neutrophil count [ANC]: $<500$ cells/ $\mu \mathrm{L}$ ) before the diagnosis of HSC was 19 days (range, 8-45 days). Seventy-eight percent of patients (28/38) died, whereas the median survival from HSC diagnosis was 9.5 months. Patients in remission had a longer survival than those with newly diagnosed or refractory or relapsed leukemia $(P=0.0065) .{ }^{10}$ Similarly, Sallah et al, in a retrospective US

Table I Overview of liver fungal infections in different types of patients

\begin{tabular}{|c|c|c|c|}
\hline Host & Candida & Aspergillus & Other fungi \\
\hline $\begin{array}{l}\text { Oncohematologic } \\
\text { patients }\end{array}$ & $\begin{array}{l}\text { Incidence reduced after introduction } \\
\text { of primary systemic antifungal } \\
\text { prophylaxis. The main risk factor is } \\
\text { severe and prolonged neutropenia }\end{array}$ & $\begin{array}{l}\text { Mainly due to disseminated disease. } \\
\text { Primary hepatic infection is not very } \\
\text { frequent. The strongest risk factor is } \\
\text { prolonged neutropenia }\end{array}$ & $\begin{array}{l}\text { Unusual complication among } \\
\text { oncohematologic patients. Liver fungal } \\
\text { infections due to endemic fungi should } \\
\text { be suspected in patients from certain } \\
\text { geographic areas }\end{array}$ \\
\hline $\begin{array}{l}\text { Non-oncohematologic } \\
\text { patients }\end{array}$ & $\begin{array}{l}\text { Unusual complication among } \\
\text { immunocompetent patients. Biliary } \\
\text { tract infections were described mainly } \\
\text { in patients with PSC }\end{array}$ & $\begin{array}{l}\text { Unusual complication among } \\
\text { immunocompetent patients. Biliary } \\
\text { tract infections were described mainly } \\
\text { in patients with PSC }\end{array}$ & Anecdotal cases \\
\hline Neonates and children & $\begin{array}{l}\text { Unusual complication among neonates } \\
\text { and children. Mainly in disseminated } \\
\text { candidiasis }\end{array}$ & Anecdotal cases & Anecdotal cases \\
\hline Liver transplantation & $\begin{array}{l}\text { Thrombosis of hepatic artery is the } \\
\text { main risk factor. Increased risk in } \\
\text { selected patients (high-risk patients) }\end{array}$ & $\begin{array}{l}\text { Thrombosis of hepatic artery is the } \\
\text { main risk factor. Increased risk in } \\
\text { selected patients (high-risk patients) }\end{array}$ & $\begin{array}{l}\text { Liver fungal infections due to endemic } \\
\text { fungi should be suspected in patients } \\
\text { from certain geographic areas }\end{array}$ \\
\hline HIV patients & $\begin{array}{l}\text { Unusual complication among HIV } \\
\text { patients }\end{array}$ & $\begin{array}{l}\text { Unusual complication among HIV } \\
\text { patients }\end{array}$ & Endemic mycoses are possible \\
\hline
\end{tabular}

Abbreviations: HIV, human immunodeficiency virus; PSC, primary sclerosing cholangitis.

Table 2 Summary of findings from studies on HSC in patients with oncohematologic malignancies

\begin{tabular}{|c|c|c|c|c|c|}
\hline Reference & Type of study & Country & Time span & HSC cases & Comments \\
\hline Anttila et $\mathrm{al}^{10}$ & Retrospective cohort & Finland & $1980-1993$ & 38 & $\begin{array}{l}6.8 \% \text { cases among } 562 \text { adult patients suffering } \\
\text { from acute leukemia; death rate equal to } 78 \%\end{array}$ \\
\hline Sallah et al" & Retrospective cohort & USA & $1990-1998$ & 23 & $\begin{array}{l}\text { Review of HSC cases in patients with acute } \\
\text { leukemia; mortality rate equal to } 17.4 \%\end{array}$ \\
\hline Pagano et al ${ }^{12}$ & Retrospective cohort & Italy & $1990-2000$ & 28 & $\begin{array}{l}\text { Review of HSC cases in patients with different } \\
\text { oncohematologic malignancies; fatality rate } \\
\text { equal to } 15 \%\end{array}$ \\
\hline Chen et $\mathrm{al}^{1 / 4}$ & Retrospective cohort & Taiwan & $1995-2002$ & 37 & $\begin{array}{l}7.4 \% \text { cases among } 500 \text { adult patients suffering } \\
\text { from acute leukemia; death rate equal to } 18.9 \%\end{array}$ \\
\hline De Castro et $\mathrm{al}^{7}$ & Retrospective cohort & France & $2000-2007$ & 24 & $\begin{array}{l}\text { Review of HSC cases in patients with different } \\
\text { oncohematologic malignancies; fatality rate } \\
\text { equal to } 46 \%\end{array}$ \\
\hline Sallah et $a^{16}$ & Retrospective cohort & USA & $1990-1998$ & 23 & $\begin{array}{l}5.4 \% \text { cases among } 423 \text { patients suffering from } \\
\text { acute leukemia }\end{array}$ \\
\hline
\end{tabular}

Abbreviation: HSC, hepatosplenic candidiasis. 
Table 3 Summary of findings on liver fungal infections in patients who had undergone liver transplantation

\begin{tabular}{|c|c|c|c|}
\hline Reference & Type of study & Country & Comments \\
\hline Annunziata et $\mathrm{al}^{51}$ & Case report & USA & $\begin{array}{l}\text { Hepatic abscess by Candida glabrata in a } 48 \text {-year-old man } 8 \text { years after } \\
\text { OLT }\end{array}$ \\
\hline Fortún et $\mathrm{al}^{52}$ & Case series & Spain & $\begin{array}{l}\text { Description of four cases with C. glabrata, one with a frank hepatic } \\
\text { abscess, the others with fungal isolation from the bile }\end{array}$ \\
\hline Alexander et $\mathrm{a}^{53}$ & $\begin{array}{l}\text { Retrospective } \\
\text { cohort }\end{array}$ & Germany & $\begin{array}{l}\text { One case of liver fungal infection by } C \text {. glabrata among } 28 \text { cases of IFls } \\
\text { post-OLT }\end{array}$ \\
\hline Musso et $\mathrm{al}^{55}$ & Case report & Italy & Bilioma related to Candida norvegensis in a 47 -year-old man \\
\hline Mazza et a ${ }^{56}$ & Case report & France & $\begin{array}{l}\text { Liver abscess caused by Aspergillus fumigatus in a woman } 3 \text { years after } \\
\text { OLT }\end{array}$ \\
\hline Vucicevic et al ${ }^{57}$ & $\begin{array}{l}\text { Retrospective } \\
\text { cohort }\end{array}$ & USA & One case of hepatic coccidioidomycosis out of 39I patients post-OLT \\
\hline Abboud et $\mathrm{al}^{59}$ & Case report & Brazil & Liver abscess related to mucormycosis in a 23 -year-old woman \\
\hline Davari et al ${ }^{60}$ & Case series & Iran & $\begin{array}{l}\text { Hepatic involvement in two patients out of four with diagnosis of } \\
\text { mucormycosis after OLT among } 5 \mathrm{I} \text { liver transplant recipients }\end{array}$ \\
\hline
\end{tabular}

Abbreviations: IFI, invasive fungal infection; OLT, orthotopic liver transplantation.

Table 4 Uncommon causative pathogens of liver fungal infections in patients with oncohematologic malignancies

\begin{tabular}{|c|c|c|c|}
\hline Causative agent & $\begin{array}{l}\text { Reference } \\
\text { Type of study }\end{array}$ & Country & Comments \\
\hline Rhodotorula spp. & $\begin{array}{l}\text { Rusthoven et a }{ }^{23} \\
\text { Case report }\end{array}$ & USA & Patient with acute myelogenous leukemia \\
\hline Trichosporon loubieri & $\begin{array}{l}\text { Bhaskaran et al }{ }^{24} \\
\text { Case report }\end{array}$ & USA & $\begin{array}{l}\text { Patient with relapsed B-cell acute lymphoblastic } \\
\text { leukemia after an allogeneic HSCT }\end{array}$ \\
\hline Geotrichum capitatum & $\begin{array}{l}\text { Amft et } \mathrm{al}^{25} \\
\text { Case report }\end{array}$ & Italy & Patient with non-Hodgkin's lymphoma \\
\hline Cryptococcus neoformans & $\begin{array}{l}\text { Liu et } \mathrm{a}^{26} \\
\text { Case report } \\
\text { Suzuki et } \mathrm{a}^{27} \\
\text { Case report }\end{array}$ & $\begin{array}{l}\text { Taiwan } \\
\text { Japan }\end{array}$ & $\begin{array}{l}\text { Patient with myelodysplastic syndrome and } \\
\text { cryptococcal meningoencephalitis } \\
\text { Old patient with HTLV-I }\end{array}$ \\
\hline Mucormycosis & $\begin{array}{l}\text { Khan et } \mathrm{a}^{28} \\
\text { Case report } \\
\text { Oliver et } \mathrm{a}^{29} \\
\text { Case report }\end{array}$ & $\begin{array}{l}\text { India } \\
\text { USA }\end{array}$ & $\begin{array}{l}\text { Young patient with acute lymphoblastic leukemia on } \\
\text { chemotherapy } \\
\text { Bone marrow transplant recipient in whom hepatic } \\
\text { fungal infection developed after ingestion of multiple } \\
\text { naturopathic medicines }\end{array}$ \\
\hline Pneumocystis jirovecii & $\begin{array}{l}\text { Cordonnier et } \mathrm{al}^{31} \\
\text { Fifth European Conference on } \\
\text { Infections in Leukemia (ECIL-5) }\end{array}$ & Different nations & $\begin{array}{l}\text { Pneumonia is rare in HSCT recipients unless patients } \\
\text { do not comply with antifungal prophylaxis }\end{array}$ \\
\hline
\end{tabular}

Abbreviations: HSCT, hematopoietic stem cell transplantation; HTLV, human T-lymphotropic virus.

study conducted from 1990 to 1998 , analyzed 23 cases of HSC in patients with acute leukemia (AML 15 and ALL 8). All patients but 3 had a remission of leukemia. The median duration of neutropenia before the diagnosis of HSC was 17 days (range, 12-38 days); 4 patients died within 1-6 months from the time of diagnosis. ${ }^{11}$ In a retrospective Italian study conducted in 1990s, Pagano et al evaluated 28 cases of HSC in hospitalized patients with hematologic malignancies. According to the 2002 European Organization for Research and Treatment of Cancer/Mycoses Study Group definition, the cases were classified as proven (18 cases; $64 \%$ ), probable ( 8 cases; $29 \%$ ), and possible ( 2 cases; $7 \%$ ) infection. AML ( 20 cases; $71 \%$ ), ALL ( 5 cases; $18 \%$ ), and non-Hodgkin's lymphoma ( 3 cases; $11 \%$ ) were the under- lying hematologic diseases of the observed patients. HSC was diagnosed after the remission of neutropenia in 54\% of patients (15/28 cases), whereas in the remaining $46 \%(13 / 28$ cases) it was observed before the chemotherapy. About $80 \%$ of cases had a severe (ANC: $<500$ cells $/ \mu \mathrm{L}$ ) and prolonged (median of 20 days) neutropenia before the onset of HSC; on the contrary, at the time of diagnosis, almost all of the patients (25/28 cases) had a high ANC. Systemic antifungal prophylaxis had been administered only in $14 \%$ of the cases ( $3 / 22$ patients), whereas the remaining ones (19/22 patients; $86 \%$ ) had received topical antifungal prophylaxis. Only nine patients had a positive blood culture: C. albicans (5 cases), C. parapsilosis (1 case), C. krusei (1 case), C. tropicalis plus C. lipolytica (1 case), and C. albicans plus C. tropicalis 
Table 5 Uncommon causative pathogens of liver fungal infections in patients without oncohematologic malignancies

\begin{tabular}{|c|c|c|c|}
\hline Causative agent & $\begin{array}{l}\text { Reference } \\
\text { Type of study }\end{array}$ & Country & Patient's underlying condition \\
\hline \multirow[t]{2}{*}{ Phaeoacremonium parasiticum } & Marciano et $\mathrm{al}^{33}$ & USA & Chronic granulomatous disease \\
\hline & Retrospective cohort & & \\
\hline \multirow[t]{6}{*}{ Basidiobolomycosis } & Hassan et al ${ }^{42}$ & Iraq & Biliary tract diseases \\
\hline & Retrospective cohort & & \\
\hline & van den Berk et al ${ }^{43}$ & The Netherlands & \\
\hline & Case report & & \\
\hline & Geramizadeh et al ${ }^{50}$ & Iran & Neonates and children \\
\hline & Case report & & \\
\hline \multirow[t]{2}{*}{ Coccidioides spp. } & Vucicevic et $\mathrm{a}^{57}$ & USA & Orthotopic liver transplantation \\
\hline & Retrospective cohort & & \\
\hline \multirow[t]{4}{*}{ Mucormycosis } & Abboud et $\mathrm{al}^{59}$ & Brazil & \\
\hline & Case report & & \\
\hline & Davari et al ${ }^{60}$ & Iran & \\
\hline & Case report & & \\
\hline \multirow[t]{2}{*}{ Cryptococcus neoformans } & Cazorla et $\mathrm{al}^{63}$ & France & Human immunodeficiency virus \\
\hline & Case report & & \\
\hline
\end{tabular}

(1 case). Candida spp. were found only in 6 out of 15 patients who had biopsies. The overall mortality rate was about 15\% (4/28 patients); however, all patients delayed the treatment for the underlying hematologic disease. ${ }^{12,13}$ From 1995 to 2002, Chen et al found 37 (7.4\%) cases of HSC out of 500 adult patients with acute leukemia receiving chemotherapy. Fifteen patients had proven infection; instead, 22 were considered to have probable infection. No rate difference was observed between the patients with AML and those with ALL (29/378 patients [7.7\%] versus 8/122 patients [6.6\%], respectively). Overall, only seven patients died due to HSC. ${ }^{14}$ In a retrospective French study, De Castro et al analyzed 24 cases of HSC in oncohematologic patients (during the period 2000 to 2007) occurred in two major Paris centers for the management of hematologic malignancies. Acute leukemia (ALL or AML, 18 cases; 75\%), lymphoma (4 cases; 17\%), autologous HSCT ( 1 case; 4\%), and chronic neutropenia ( 1 case; 4\%) were the underlying hematologic conditions of the patients. All cases were classified according to the revisited European Organization for Research and Treatment of Cancer/Mycoses Study Group criteria for IFIs: proven ( 6 cases; $25 \%$ ), probable ( 3 cases; $12.5 \%$ ), and possible (15 cases; $62.5 \%$ ) infection. All cases occurred in patients who did not receive antifungal prophylaxis and almost all patients were colonized by Candida spp. Four patients died within 3 months after the HSC diagnosis; the overall mortality during the scheduled follow-up period was $46 \%$ ( $11 / 24$ subjects). In the multivariate analysis, failure of hematologic remission at the HSC diagnosis (hazard ratio 5.60, 95\% CI: $1.39-22.5 ; P=0.015$ ) and long duration (>1 month) of neutropenia (hazard ratio $4.33,95 \% \mathrm{CI}$ :
$1.24-15.2 ; P=0.022$ ) were the only independent predictors of death. ${ }^{715}$ Finally, in another retrospective study, Sallah et al found that younger age (odds ratio [OR] 1.96, 95\% CI: $1.72-2.99 ; P=0.009$ ), duration of neutropenia $\geq 15$ days (OR 11.7, 95\% CI: 3.04-45.1; $P=0.0003$ ), and use of prophylactic quinolones (OR 3.85, 95\% CI: $1.11-13.4 ; P=0.039$ ) were the only independent predictors of the development of HSC in patients with acute leukemia. ${ }^{16}$ In Table 2, data from the above-mentioned studies are summarized.

\section{Aspergillus}

Aspergillosis is the most common mold infection in oncohematologic setting. ${ }^{17}$ A. fumigatus is the most commonly isolated species to cause invasive aspergillosis (IA); however, an increased incidence of non-fumigatus Aspergillus spp. is a major concern in oncohematologic patients. ${ }^{18}$ Pulmonary infection is the most frequent form of IA in immunocompromised patients, including patients with hematologic malignancies and HSCT recipients; at any rate, extrapulmonary IA can develop within any anatomic site and disseminated disease is particularly common among patients with prolonged neutropenia. ${ }^{19}$ Furthermore, isolated primary extrapulmonary infection, such as gastrointestinal and hepatic involvement, has been described. ${ }^{20-22}$

\section{Other fungi}

Hepatic involvement due to invasive yeast infections other than Candida spp. is an unusual complication in oncohematologic patients. Based on our knowledge, hepatic fungal infections due to Rhodotorula spp., Trichosporon spp., Geotrichum spp., and Cryptococcus spp. have been 
described in this context. ${ }^{23-27}$ Although invasive mold infections by pathogens other than Aspergillus spp. are an emerging cause of opportunistic mycoses in patients with hematologic malignancies, only rarely has hepatic involvement been reported. ${ }^{28,29}$ Eventually, involvement of the liver is possible in the endemic fungal infections, such as blastomycosis, coccidioidomycosis, and histoplasmosis, whereas hepatic pneumocystosis has been reported exclusively in HIV-infected individuals. ${ }^{30,31}$ Uncommon causative pathogens of liver fungal infections in patients with oncohematologic malignancies are summarized in Table 4.

\section{Patients without oncohematologic malignancies \\ Chronic granulomatous disease (CGD) Candida}

Lublin et al analyzed the clinical presentation, diagnostic procedures, and surgical management of hepatic abscesses in patients with CGD between 1980 and 2000. Of 61 cases of hepatic abscess, 22 patients with CGD were treated at the local National Institutes of Health; the median age at the time of initial hepatic abscess presentation was 14 years. Subjective fever was the most frequent presenting symptom, and the erythrocyte sedimentation rate was elevated in $98 \%$ of cases. Fifty-two cases were managed surgically and eight cases were managed with percutaneous drainage. One patient refused surgery. The surgical complication rate was $56 \%$; however, there were no deaths directly related to the hepatic abscesses. Staphylococcus aureus was the most frequent organism identified in culture ( 23 cases [ $88 \%$ of all positive cultures]), followed by one case each of Nocardia and Lactobacillus and one case consisting of multiple organisms (C. glabrata, Streptococcus mitis, and $S$. aureus). No organism was cultured in $15(37 \%)$ cases. $^{32}$

\section{Aspergillus}

Marciano et al assessed the impact of common severe infections in CGD by examining the records of 268 patients followed at a single center over four decades. Fungal infection accounted for 21 deaths (21/38 [55\%]). Overall Aspergillusspecific mortality was $9 \%$. A. fumigatus was isolated from 10 patients, A. tanneri from 2 patients, and $A$. nidulans was identified from 1 fatal fungal infection. In three cases, Candida spp. were isolated as a possible cause of death. ${ }^{33}$ Mamishi et al described an Aspergillus osteomyelitis of the ribs and hepatic abscess in a 5-year-old boy. The patient was successfully treated with amphotericin B. ${ }^{34}$

\section{Other fungi}

Other fungi, such as Phaeoacremonium parasiticum, have been described in patients with CGD. ${ }^{33}$

\section{Biliary tract diseases \\ Candida}

Kulaksiz et al analyzed 148 bile samples taken at endoscopic examination of 67 consecutive patients with primary sclerosing cholangitis (PSC). Candida spp. were found in $>8 \%$ of patients. This study suggests that candidal infection of the bile ducts should be considered in the empirical treatment of patients with PSC..$^{35}$ Lima et al reported a rare case of C. glabrata liver abscess and fungemia complicating acute calculus cholecystitis in a 64-year-old female patient who had no history of immunosuppression or diabetes mellitus. The patient underwent cholecystectomy, resection of liver abscess, and systemic antifungal therapy. ${ }^{36}$ Lai et al reported a case of candidal liver abscesses and concomitant candidal cholecystitis in a diabetic patient. Bile and aspirated pus culture repeatedly tested positive, and blood negative, for C. albicans and C. glabrata. Cholecystitis was cured by percutaneous gallbladder drainage and amphotericin B therapy. ${ }^{37}$ Friedman et al described a case of a 39-year-old man with severe diabetes mellitus, chronic pancreatic insufficiency, intrapancreatic choledochal stricture, and secondary biliary cirrhosis, who developed postsurgical fungemia and large hepatic abscesses due to C. glabrata. ${ }^{38}$ Melero et al described a case of PSC and Crohn's disease with multiple fungal liver abscesses caused by $C$. albicans. The patient had developed a duodenal-biliary fistula. Antibiotic therapy produced clinical response, and surgery was performed to repair the fistula. ${ }^{39}$

\section{Aspergillus}

Kulaksiz et al analyzed 148 bile samples taken at endoscopic examination of 67 consecutive patients with PSC. Aspergillus spp. were not found. This study suggests that infection of the bile ducts by this mold should not be considered in the empirical treatment of patients with PSC. ${ }^{35}$ Erdman et al reported a case of a 19-year-old girl with a history of recurrent late-onset, febrile cholangitis after a portoenterostomy ${ }^{40} \mathrm{~A}$. terreus was isolated from her biliary fluid obtained at percutaneous transhepatic cholangiography. Moreover, A. fumigatus was described as a superinfection of a bilioma. ${ }^{41}$ 


\section{Other fungi}

Recently, biliary tract disease related to fascioliasis was seen to be complicated by basidiobolomycosis. ${ }^{42}$ Usually, basidiobolomycosis is a subcutaneous infection, but rarely, if undiagnosed, can provoke a fatal hepatic infection, even in adult immunocompetent patients. ${ }^{43}$

\section{Neonates and children Candida}

In newborns, Candida spp. infections are the leading cause of IFIs, which are potentially life-threatening. ${ }^{44}$ Sharma et al reported a case of $C$. albicans liver abscess in a preterm neonate, secondary to malposition of umbilical lines that presented with respiratory difficulty and other clinical features of sepsis, which were managed medically and the infant was discharged successfully. ${ }^{45}$ Picone et al reported the case of a 31-week gestational age neonate with $C$. albicans sepsis and a hepatic abscess. Diagnosis relied on clinical and radiologic signs of sepsis, liver function impairment, and culture isolation of Candida spp. from the sterile sites. Liver ultrasound documented the presence of a multiloculated abscess. Treatment with micafungin resulted in normalization of liver function, inflammatory laboratory values, and improvement of clinical condition. After 30 days of treatment, the liver abscess resolved, and at the 8-month follow-up, the infant is doing well. Prompt diagnosis and antifungal treatment avoided surgical drainage and liver surgery in this high-risk neonate. ${ }^{46}$ Of note, $C$. parapsilosis is increasingly being recognized as an important cause of invasive candidiasis in neonates. ${ }^{47,48}$

\section{Aspergillus}

A. terreus is reported in an immunocompromised child; he was affected by common variable immunodeficiency and the hepatic infection occurred while the patient was receiving secondary prophylaxis with fluconazole after an episode of pulmonary candidiasis. ${ }^{49}$

\section{Other fungi}

Geramizadeh et al described for the first time a case of an isolated liver involvement of basidiobolomycosis in a 2-year-old girl, who presented with a liver mass resembling a hepatic abscess. ${ }^{50}$

\section{Liver transplantation \\ Candida}

When Candida spp. have been determined as a causative agent of hepatic abscesses following orthotopic liver transplantation (OLT), non-albicans species have played an important role. In 1997, Annunziata et al illustrated the case of a 48-year-old man who had developed a hepatic abscess by $C$. glabrata 8 years after OLT. The authors attributed the phenomenon to the stenosis of hepatic artery, resulting in bile infarcts presumably contaminated through the biliary tract with yeast from the biliary-enteric anastomosis. The combination of percutaneous drainage and medical therapy with amphotericin B for 10 weeks allowed a safe and decisive retransplantation. ${ }^{51}$ In 1997, Fortún et al described four cases of IFI post-OLT due to C. glabrata of which in three cases the yeast was isolated from the biliary material; of these last three cases an abscess was reported only in one case. The abscess treatment included amphotericin B plus drainage, and the patient recovered uneventfully. ${ }^{52}$ C. glabrata was also found as responsible in the only case of IFIs related to fungal liver infection in a German retrospective study including 28 cases of IFIs following OLT. The study was aimed at establishing the role of hepatic iron overload (measured in the liver explants by Perl's Prussian blue stain) as a risk factor of IFIs. ${ }^{53}$ Although this association is not elucidated in detail, this information represents another tile in the mosaic of the factors predisposing to IFIs after OLT. ${ }^{54}$ Another non-albicans form was described in a more recent case report from Italy involving a 47-year-old man suffering from a deep-seated candidiasis following OLT. Cultural examination of material from bilioma revealed C. norvegensis, a rare species characterized by an inherent resistance to fluconazole. The clinical outcome of the patient was positive owing to the endoscopic procedure plus treatment with anidulafungin. ${ }^{55}$

\section{Aspergillus}

Mazza et al described, in 1996, the case of a woman who had undergone an OLT in 1992 and, 3 years later, presented with a clinical picture of persistent fever, asthenia, and alteration of liver enzymes; imaging examination showed fluid collection in the left liver lobe. A. fumigatus was isolated from the material obtained via aspiration, and therapy with itraconazole was successfully started. No entry site was identified; of note, the patient had been diagnosed with a Burkitt's lymphoma just 18 months earlier and consequently treated with chemotherapy which was another risk factor. ${ }^{56}$

\section{Other fungi}

Vucicevic et al, in a comprehensive retrospective review of medical records of 391 liver transplant recipients from June 1999 to December 2007, found 1 case of hepatic 
coccidioidomycosis (out of 12 post-OLT infections by Coccidioides spp.). ${ }^{57}$ Coccidioidomycosis is to be suspected in endemic areas (such as southwestern USA and some parts of Central America and South America) and in immunosuppressed patients; pulmonary manifestations are the most frequent ones, but a disseminated disease with the involvement of different organs is possible. ${ }^{58}$ Abboud et al reported the case of a 23-year-old woman with a history of OLT due to PSC. Forty-seven days later, she presented with fever and pain at the right hypochondrium; abdominal ultrasound scanning demonstrated a hepatic abscess in the right lobe. Histopathologic examination following liver biopsy revealed diagnosis of mucormycosis; she was successfully treated with the sequential use of amphotericin B and posaconazole without surgery. Of note, the donor himself was under immunosuppressive therapy, being a kidney transplant recipient; so, the fungal infection might have been transmitted by the allograft. ${ }^{59}$ Two cases of liver mucormycosis after OLT, among a small series of four, had been previously described by Iranian authors, which were unfortunately characterized by unfavorable outcome, although both underwent therapy with amphotericin B and one case had aggressive surgical debridement. ${ }^{60}$ As a matter of fact, mucormycosis, a lifethreatening infection due to fungi of the order Mucorales, is burdened with a very high fatality rate. ${ }^{61}$ In Table 3 , data regarding liver fungal infections after OLT are summarized.

\section{HIV}

\section{Candida}

Alvarez et al illustrated in 2000 a case of a young woman with advanced HIV disease who presented with two hypoechoic lesions in the left liver lobe. These lesions were of polimicrobial origin, and C. albicans turned out to be one of the culprits. After adequate antifungal treatment, the patient was discharged and then was lost to follow-up. ${ }^{62}$

\section{Other fungi}

Cazorla et al, describing a small case series of extracerebral cryptococcosis, reported the case of a 39-year-old man infected with HIV and with a liver abscess related to C. neoformans. ${ }^{63}$

\section{Conclusion}

IFIs have become a leading cause of morbidity and mortality in oncohematologic patients and HSCT hosts. ${ }^{18}$

Of course, these subjects are generally prone to develop other kinds of infections also. For example, without a proper prophylaxis, the risk of hepatitis $\mathrm{B}$ reactivation ranges from
$18 \%$ to $73 \%$, and is about $61 \%$ in HBsAg positive patients with lymphoma and acute leukemia, respectively; the risk is $34 \%-68 \%$ and $2.8 \%-12.5 \%$, respectively, in individuals with the same pathologies but are HBsAg negative and anti-HBc positive. ${ }^{64} \mathrm{~B}$-cell-depleting agents, anthracycline, and high doses of steroids pose the highest risk of hepatitis $B$ reactivation in the oncohematologic setting. ${ }^{65}$

Another relevant issue is represented by bacterial infections, a dramatic problem in the era of antimicrobial resistance. ${ }^{66}$ In a large Spanish cohort reviewing 991 cases of HSCT, 44 episodes of bloodstream bacterial infections per 10,000 transplant days in allogeneic HSCT recipients were described.$^{67}$ Febrile neutropenia occurs in up to $80 \%$ of patients with hematologic malignancies, and major bacterial infections such as the ones of the bloodstream are held accountable in $10 \%-25 \%$ of cases. ${ }^{68}$

Focusing on IFIs, there are several studies investigating their incidence and the main risk factors linked with their development, although it is not simple to account for the large variety of malignant diseases and for the different treatment strategies, each of them carrying distinct risk profiles. For sure, infections by Aspergillus spp. have overcome the ones by Candida spp., a shift probably driven by the role of antifungal prophylaxis. ${ }^{69}$ Overall, AML is the disease having the major risk of IFIs, which varies from $10 \%$ to $25 \%$; in chronic lymphoproliferative disorders, the incidence of IFIs ranges from $0.5 \%$ to $10.8 \%$. The incidence of IFIs is from $3 \%$ to $8 \%$ among autologous HSCT recipients and from $7 \%$ to $15 \%$ among allogeneic HSCT recipients; in other categories (e.g., myeloproliferative neoplasms), data are scarce and related to old cohorts. ${ }^{70}$

A liver abscess can mainly develop after translocation of fungi from the gut to the liver via the portal circulation, but it is an unusual occurrence. ${ }^{71,72}$ Overall, the major risk factors for IFIs in these patients are the underlying malignancy, neutropenia, and the degree of immunosuppression. ${ }^{73-77}$ Fungal infections represent a less common cause of hepatic abscesses among patients without oncohematologic malignancies. ${ }^{78,79}$ Hepatic abscesses are common in tropical countries and are most commonly caused by Candida spp. ${ }^{79}$ Although hepatic involvement due to Candida spp. may affect immunocompetent patients without any comorbidity, in the nononcohematologic setting, individuals more prone to fungal infections of the liver, not exclusively by Candida spp., usually suffer from distinct clinical conditions. ${ }^{80}$ Fungal hepatic involvement after OLT is a relatively rare, but potentially severe complication. Thrombosis of hepatic artery seems to be the most important predisposing factor. Although bacteria 
represent the most common causative agents, fungi cannot be neglected in the differential diagnosis, considering their impact, in terms of morbidity and mortality, in the setting of posttransplantation infections. ${ }^{81}$ Indeed, in the light of the recommendations from the most authoritative international societies, antifungal prophylaxis following OLT, to prevent IFIs, is not mandatory for low-risk patients, but it is necessary under several circumstances: 1) only against Candida spp. for patients with perioperative Candida colonization complicated operations or choledochojejunostomy anastomosis and 2) against both Candida and Aspergillus for patients at high risk, undergoing renal replacement therapy posttransplant and with the high probability of reoperation. ${ }^{82}$ Finally, the management of patients suffering from HIV and diagnosed with fungal hepatic abscesses should follow the same rules as non-HIV patients; however, data from literature are poor, particularly when it comes with fungal hepatic abscesses. ${ }^{83,84}$

\section{Acknowledgments}

We are grateful to Dr Alessandra Trocino and Mrs Mariacristina Romano from the National Cancer Institute of Naples for providing excellent bibliographic service and assistance.

\section{Author contributions}

This review was mainly written by MF and MC. AEM and MF collected the data. IG, SB, VS, and MCP supervised the writing of the paper. All authors contributed toward data analysis, drafting, and critically revising the paper, gave final approval of the version to be published, and agree to be accountable for all aspects of the work.

\section{Disclosure}

The authors report no conflicts of interest in this work.

\section{References}

1. Esposito S, Leone S, Carosi G. Analysis of current guidelines for intraabdominal infections. J Chemother. 2009;21(Suppl 1):30-35.

2. Esposito S, Leone S, Noviello S. Management of severe bacterial infections. Expert Rev Anti Infect Ther. 2005;3(4):593-600.

3. Leone S, Stefani S, Venditti M, et al; Italian Intra-abdominal Infections Working Group. Intra-abdominal infections: model of antibiotic stewardship in an era with limited antimicrobial options. Int J Antimicrob Agents. 2011;38(3):271-272.

4. Kontoyiannis DP, Luna MA, Samuels BI, Bodey GP. Hepatosplenic candidiasis. A manifestation of chronic disseminated candidiasis. Infect Dis Clin North Am. 2000;14(3):721-739.

5. Bodey GP. Fungal infections complicating acute leukemia. $J$ Chronic Dis. 1966;19(6):667-687.

6. Bodey GP, DeJongh D, Isassi A, Freireich EJ. Hypersplenism due to disseminated candidiasis in a patient with acute leukemia. Cancer. 1969;24(2):417-420.
7. De Castro N, Mazoyer E, Porcher R, et al. Hepatosplenic candidiasis in the era of new antifungal drugs: a study in Paris 2000-2007. Clin Microbiol Infect. 2012;18(6):e185-e187.

8. Cornely OA, Maertens J, Winston DJ, et al. Posaconazole versus. fluconazole or itraconazole prophylaxis in patients with neutropenia. N Engl J Med. 2007;356(4):348-359.

9. Vehreschild JJ, Böhme A, Buchheidt D, et al. A double-blind trial on prophylactic voriconazole (VRC) or placebo during induction chemotherapy for acute myelogenous leukemia (AML). J Infect. 2007;55(5):445-449.

10. Anttila VJ, Elonen E, Nordling S, Sivonen A, Ruutu T, Ruutu P. Hepatosplenic candidiasis in patients with acute leukemia: incidence and prognostic implications. Clin Infect Dis. 1997;24(3):375-380.

11. Sallah S, Semelka RC, Wehbie R, Sallah W, Nguyen NP, Vos P. Hepatosplenic candidiasis in patients with acute leukemia. Br J Haematol. 1999;106(3):697-701.

12. Pagano L, Mele L, Fianchi L, et al. Chronic disseminated candidiasis in patients with hematologic malignancies. Clinical features and outcome of 29 episodes. Haematologica. 2002;87(5):535-541.

13. Ascioglu S, Rex JH, de Pauw B, et al. Defining opportunistic invasive fungal infections in immunocompromised patients with cancer and hematopoietic stem cell transplants: an international consensus. Clin Infect Dis. 2002;34(1):7-14.

14. Chen CY, Chen YC, Tang JL, et al. Hepatosplenic fungal infection in patients with acute leukemia in Taiwan: incidence, treatment, and prognosis. Ann Hematol. 2003;82(2):93-97.

15. De Pauw B, Walsh TJ, Donnelly JP, et al; European Organization for Research and Treatment of Cancer/Invasive Fungal Infections Cooperative Group; National Institute of Allergy and Infectious Diseases Mycoses Study Group (EORTC/MSG) Consensus Group. Revised definitions of invasive fungal disease from the European Organization for Research and Treatment of Cancer/Invasive Fungal Infections Cooperative Group and the National Institute of Allergy and Infectious Diseases Mycoses Study Group (EORTC/MSG) Consensus Group. Clin Infect Dis. 2008;46(12):1813-1821.

16. Sallah S, Wan JY, Nguyen NP, Vos P, Sigounas G. Analysis of factors related to the occurrence of chronic disseminated candidiasis in patients with acute leukemia in a non-bone marrow transplant setting: a followup study. Cancer. 2001;92(6):1349-1353.

17. Vazquez L. Antifungal prophylaxis in immunocompromised patients. Mediterr J Hematol Infect Dis. 2016;8(1):e2016040.

18. Leventakos K, Lewis RE, Kontoyiannis DP. Fungal infections in leukemia patients: how do we prevent and treat them? Clin Infect Dis. 2010;50(3):405-415.

19. Cadena J, Thompson GR 3rd, Patterson TF. Invasive aspergillosis: current strategies for diagnosis and management. Infect Dis Clin North Am. 2016;30(1):125-142.

20. van der Velden WJ, Blijlevens NM, Klont RR, Donnelly JP, Verweij PE. Primary hepatic invasive aspergillosis with progression after rituximab therapy for a post transplantation lymphoproliferative disorder. Ann Hematol. 2006;85(9):621-623.

21. Chasan R, Patel G, Malone A, Finn M, Huprikar S. Primary hepatic aspergillosis following induction chemotherapy for acute leukemia. Transpl Infect Dis. 2013;15(3):e201-e205.

22. Esposito S, Carosi G, Leone S. Intra-abdominal infections: analysis of current guidelines. Infez Med. 2008;16(Suppl 1):46-52.

23. Rusthoven JJ, Feld R, Tuffnell PG. Systemic infection by Rhodotorula spp. in the immunocompromised host. $J$ Infect. 1984;8(3): 241-246.

24. Bhaskaran A, Obeid KM, Arbefeville S, Ferrieri P. Trichosporon loubieri fungemia in a 39-year-old Caucasian woman with B-cell lymphoblastic leukemia. Lab Med. 2016;47(3):255-258.

25. Amft N, Miadonna A, Viviani MA, Tedeschi A. Disseminated Geotrichum capitatum infection with predominant liver involvement in a patient with non Hodgkin's lymphoma. Haematologica. 1996;81(4):352-355. 
26. Liu PY, Yang Y, Shi ZY. Cryptococcal liver abscess: a case report of successful treatment with amphotericin-B and literature review. Jpn J Infect Dis. 2009;62(1):59-60.

27. Suzuki T, Ichiki Y, Kamihira T, et al. [A case of hepatic cryptococcosis complicated by adult T-cell leukemia]. Nihon Shokakibyo Gakkai Zasshi. 2015;112(12):2168-75. Japanese.

28. Khan AA, Kumaran V, Jain D, Siraj F, Aggarwal S. Hepatic mucormycosis in a patient of acute lymphoblastic leukemia: a case report with literature review. Indian J Hematol Blood Transfus. 2013;29(2):96-98.

29. Oliver MR, Van Voorhis WC, Boeckh M, Mattson D, Bowden RA Hepatic mucormycosis in a bone marrow transplant recipient who ingested naturopathic medicine. Clin Infect Dis. 1996;22(3):521-524.

30. Ng VL, Yajko DM, Hadley WK. Extrapulmonary pneumocystosis. Clin Microbiol Rev. 1997;10(3):4014-4018.

31. Cordonnier C, Cesaro S, Maschmeyer G, et al. Pneumocystis jirovecii pneumonia: still a concern in patients with hematological malignancies and stem cell transplant recipients. J Antimicrob Chemother. 2016;71(9):2379-2385.

32. Lublin M, Bartlett DL, Danforth DN, et al. Hepatic abscess in patients with chronic granulomatous disease. Ann Surg. 2002;235(3):383-391.

33. Marciano BE, Spalding C, Fitzgerald A, et al. Common severe infections in chronic granulomatous disease. Clin Infect Dis. 2015;60(8):1176-1183.

34. Mamishi S, Zomorodian K, Saadat F, Gerami-Shoar M, Tarazooie B, Siadati SA. A case of invasive aspergillosis in CGD patient successfully treated with Amphotericin B and INF- gamma. Ann Clin Microbiol Antimicrob. 2005;4:4.

35. Kulaksiz H, Rudolph G, Kloeters-Plachky P, Sauer P, Geiss H, Stiehl A. Biliary candida infections in primary sclerosing cholangitis. J Hepatol. 2006;45(5):711-716.

36. Lima R, Shams W, Kalra S, Borthwick T. Candida glabrata liver abscess and fungemia complicating severe acalculus cholecystitis in an immunocompetent non diabetic host. South Med J. 2010;103(3): 245-247.

37. Lai CH, Chen HP, Chen TL, Fung CP, Liu CY, Lee SD. Candidal liver abscesses and cholecystitis in a 37-year-old patient without underlying malignancy. World J Gastroenterol. 2005;11(11):1725-1727.

38. Friedman E, Blahut RJ, Bender MD. Hepatic abscesses and fungemia from Torulopsis glabrata. Successful treatment with percutaneous drainage and amphotericin B. J Clin Gastroenterol. 1987;9(6):711-715.

39. Melero JL, Bastida G, Yago M, Nevarez A, Nos P, Ponce J. Fungal liver abscesses in a patient with primary sclerosing cholangitis and Crohn's disease. Gastroenterol Hepatol. 2008;31(9):576-579.

40. Erdman SH, Barber BJ, Barton LL. Aspergillus cholangitis: a late complication after Kasai portoenterostomy. J Pediatr Surg. 2002;37(6):923-925.

41. Ioannidis JP, Snydman DR, Rohrer RJ, Freeman RB, Haug CE. Aspergillus fumigatus infection of a bilioma. Clin Infect Dis. 1995;20(5): 1427-1428.

42. Hassan HA, Majid RA, Rashid NG, et al. Eosinophilic granulomatous gastrointestinal and hepatic abscesses attributable to basidiobolomycosis and fasciolias: a simultaneous emergence in Iraqi Kurdistan. BMC Infect Dis. 2013;13:91.

43. van den Berk GE, Noorduyn LA, van Ketel RJ, et al. A fatal pseudotumor: disseminated basidiobolomycosis. BMC Infect Dis. 2006;6:140.

44. Greenberg RG, Benjamin DK Jr. Neonatal candidiasis: diagnosis, prevention, and treatment. J Infect. 2014;69(Suppl 1):19-22.

45. Sharma D, Choudhary M, Shastri S, Sharma PK. Neonatal liver abscesses due to Candida infection in a preterm infant, secondary to malpositioned umbilical lines - a rare entity. Pathog Glob Health. 2015;109(2):84-87.

46. Picone S, Manzoni P, Bedetta M, Mostert M, Benjamin DK Jr, Paolillo P. Pharmacological resolution of a multiloculated Candida spp. liver abscess in a preterm neonate. Early Hum Dev. 2013;89(Suppl 1):47-50.

47. Pammi M, Holland L, Butler G, Gacser A, Bliss JM. Candida parapsilosis is a significant neonatal pathogen: a systematic review and metaanalysis. Pediatr Infect Dis J. 2013;32(5):e206-e216.
48. Ozkaya-Parlakay A, Tezer H, Kazmacan T, Gulhan B, Unal S. Successful treatment of an infant infected with refractory $C$. parapsilosis with caspofungin. J Trop Pediatr. 2014;60(4):329-330.

49. Trachana M, Roilides E, Gompakis N, Kanellopoulou K, Mpantouraki M, Kanakoudi-Tsakalidou F. Case report. Hepatic abscesses due to Aspergillus terreus in an immunodeficient child. Mycoses. 2001;44(9-10): 415-418.

50. Geramizadeh B, Sanai Dashti A, Kadivar MR, Kord S. Isolated hepatic basidiobolomycosis in a 2-year-old girl: the first case report. Hepat Mon. 2015;15(8):e30117.

51. Annunziata GM, Blackstone M, Hart J, Piper J, Baker AL. Candida (Torulopsis glabrata) liver abscesses eight years after orthotopic liver transplantation. J Clin Gastroenterol. 1997;24(3):176-179.

52. Fortún J, López-San Román A, Velasco JJ, et al. Selection of Candida glabrata strains with reduced susceptibility to azoles in four liver transplant patients with invasive candidiasis. Eur J Clin Microbiol Infect Dis. 1997;16(4):314-318.

53. Alexander J, Limaye AP, Ko CW, Bronner MP, Kowdley KV. Association of hepatic iron overload with invasive fungal infection in liver transplant recipients. Liver Transpl. 2006;12(12):1799-1804.

54. Snydman DR. The potential role for iron overload and fungal infection in liver transplantation. Liver Transpl. 2006;12(12):1731-1732.

55. Musso M, Giannella M, Antonini M, et al. Invasive Candidiasis due to Candida Norvegensis in a Liver Transplant patient: case report and literature review. Infect Dis Rep. 2014;6(29):5374.

56. Mazza D, Gugenheim J, Toouli J, Mouiel J. Survival of a liver graft recipient treated for an aspergillar liver abscess. Clin Infect Dis. 1996;23(4):831-832.

57. Vucicevic D, Carey EJ, Blair JE. Coccidioidomycosis in liver transplant recipients in an endemic area. Am J Transplant. 2011;11(1):111-119.

58. Parish JM, Blair JE. Coccidioidomycosis. Mayo Clin Proc. 2008;83(3): 343-348.

59. Abboud CS, Bergamasco MD, Baía CES, et al. Case report of hepatic mucormycosis after liver transplantation: successful treatment with liposomal amphotericin B followed by posaconazole sequential therapy. Transplant Proc. 2012;44(8):2501-2502.

60. Davari HR, Malekhossini SA, Salahi HA, et al. Outcome of mucormycosis in liver transplantation: four cases and a review of literature. Exp Clin Transplant. 2003;1(2):147-152.

61. Spellberg B, Walsh TJ, Kontoyiannis DP, Edwards J Jr, Ibrahim AS. Recent advances in the management of mucormycosis: from bench to bedside. Clin Infect Dis. 2009;48(12):1743-1751.

62. Alvarez OA, Vanegas F, Maze GL, Gross GW, Lee M. Polymicrobial cholangitis and liver abscess in a patient with the acquired immunodeficiency syndrome. South Med J. 2000;93(2):232-234.

63. Cazorla A, Alanio A, Bretagne S, et al. Cryptococcus where they are not expected: Five case reports of extra-cerebral and extra-pulmonary cryptococcosis. Ann Pathol. 2015;35(6):479-485.

64. Pattullo V. Prevention of Hepatitis B reactivation in the setting of immunosuppression. Clin Mol Hepatol. 2016;22:219-237.

65. Coluccio C, Begini P, Marzano A, et al. Hepatitis B in patients with hematological diseases: an update. World J Hepatol. 2017;9(25):1043-1053.

66. Averbuch D, Orasch C, Cordonnier C, et al; ECIL4, a joint venture of EBMT, EORTC, ICHS, ESGICH/ESCMID and ELN. European guidelines for empirical antibacterial therapy for febrile neutropenic patients in the era of growing resistance: summary of the 20114 th European Conference on Infections in Leukemia. Haematologica. 2013;98(12):1826-1835.

67. Moreno A, Cervera C, Gavaldá J, et al. Bloodstream infections among transplant recipients: results of a nationwide surveillance in Spain. Am J Transplant. 2007;7:2579-2586.

68. Gustinetti G, Mikulska M. Bloodstream infections in neutropenic cancer patients: a practical update. Virulence. 2016;7(3):280-297.

69. Cornely OA, Gachot B, Akan H, et al; EORTC Infectious Diseases Group. Epidemiology and outcome of fungemia in a cancer Cohort of the Infectious Diseases Group (IDG) of the European Organization for Research and Treatment of Cancer (EORTC 65031). Clin Infect Dis. 2015;61(3):324-331. 
70. Pagano L, Busca A, Candoni A, et al; SEIFEM (Sorveglianza Epidemiologica Infezioni Fungine nelle Emopatie Maligne) Group. Risk stratification for invasive fungal infections in patients with hematological malignancies: SEIFEM recommendations. Blood Rev. 2017;31(2):17-29.

71. Esposito S, Capuano A, Noviello S, et al. Modification of patients' endogenous bacterial flora during hospitalization in a large teaching hospital in Naples. J Chemother. 2003;15(6), 568-573.

72. Pappas PG, Kauffman CA, Andes DR, et al. Clinical practice guideline for the management of candidiasis: 2016 update by the infectious diseases society of America. Clin Infect Dis. 2016;62(4):e1-e50.

73. Fiore M, Leone S. Use of anti-fungals in critically ill cirrhotic patients with spontaneous peritonitis. J Hepatol. 2016;64(4):986-987.

74. Fiore M, Andreana L, Leone S. Pre-emptive therapy of spontaneous fungal peritonitis. Hepatology. 2016;64(3):997-998.

75. Fiore M, Leone S. Spontaneous fungal peritonitis: epidemiology, current evidence and future prospective. World J Gastroenterol. 2016;22(34):7742-7747.

76. Fiore M, Chiodini P, Pota V, et al. Risk of spontaneous fungal peritonitis (SFP) in hospitalized cirrhotic patients with ascites: a systematic review of observational studies and meta-analysis. Minerva Anestesiol. Epub 2017 Jul 20
77. Fiore M, Maraolo AE, Leone S, et al. Spontaneous peritonitis in critically ill cirrhotic patients: a diagnostic algorithm for clinicians and future perspectives. Ther Clin Risk Manag. 2017;13:1409-1414.

78. Ghosh S, Sharma S, Gadpayle AK, et al. Clinical, laboratory, and management profile in patients of liver abscess from northern India. J Trop Med. 2014;2014:142382.

79. Petri A, Hohn J, Hodi Z, Wolfard A, Balogh A. Pyogenic liver abscess 20 years' experience. Comparison of results of treatment in two periods. Langenbecks Arch Surg. 2002;387(1):27-31.

80. Menachery J, Chawla Y, Chakrabarti A, Duseja A, Dhiman R, Kalra N. Fungal liver abscess in an immunocompetent individual. Trop Gastroenterol. 2012;33(3):232-233.

81. Kornasiewicz O, Hołówko W, Grat M, et al. Hepatic abscess: a rare complication after liver transplant. Clin Transplant. 2016;30(10):1230-1235.

82. Giannella M, Bartoletti M, Morelli M, et al. Antifungal prophylaxis in liver transplant recipients: one size does not fit all. Transpl Infect Dis. 2016;18(4):538-544.

83. Fìlice C, Brunetti E, Bruno R, Crippa FG. Clinical management of hepatic abscesses in HIV patients. Am J Gastroenterol. 2000;95(4):1092-1093.

84. Leone S, Gregis GP, Quinzan GP, et al. Causes of death and risk factors among HIV-infected persons in HAART era: analysis of a large urban cohort. Infection. 2011;39(1):13-20.
Infection and Drug Resistance

\section{Publish your work in this journal}

Infection and Drug Resistance is an international, peer-reviewed openaccess journal that focuses on the optimal treatment of infection (bacterial, fungal and viral) and the development and institution of preventive strategies to minimize the development and spread of resistance. The journal is specifically concerned with the epidemiology of antibiotic

\section{Dovepress}

resistance and the mechanisms of resistance development and diffusion in both hospitals and the community. The manuscript management system is completely online and includes a very quick and fair peerreview system, which is all easy to use. Visit http://www.dovepress.com/ testimonials.php to read real quotes from published authors. 